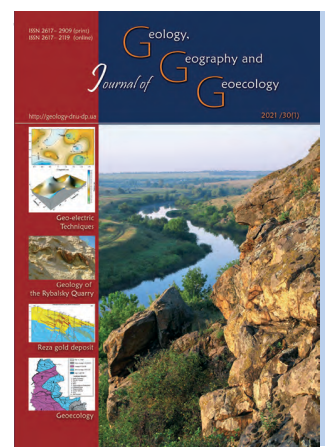

Journal of Geology.

\title{
Sacral Heritage of the Carpathian Region and Management of its Resource Component in Tourism Activity
}

\author{
Volodymyr P. Krool'1, Anatolii A. Vdovichen², Roman M. Hyshchuk², Iryna P. Dobynda ${ }^{1}$ \\ ${ }^{I} Y u r i 1$ Fedkovych Chernivtsi National University, Ukraine, kroolv@ukr.net \\ ${ }^{2}$ Chernivtsi Institute of Trade and Economics of KNUTE,Ukraine, groma2006@gmail.com
}

Received: 03.06.2020

Received in revised form: 02.12 .2020

Accepted: 04.12.2020

\begin{abstract}
The Carpathian Recreation/Tourism Region (hereafter - CRTR) in Ukraine is a unique territory featuring the sacral historic-cultural heritage of different-time periods beginning from Ancient Rus, Lithuanian, Ottoman, Austro-Hungarian and until Polish, Romanian, Czech and Ukrainian times. This is why it seems urgently necessary to assess in as
\end{abstract} much detail as possible the sacral historic-cultural heritage (hereafter - $\mathrm{HCH}$ ) of the Carpathian Recreation/Tourism Region in Ukraine and provide for the mechanisms of management of the same so that the aforementioned heritage will be as quickly and intensely as possible involved into a common cultural and tourism space and trans-border cooperation with neighboring EU countries, that is, Romania, Slovakia, Poland, Hungary and Moldova. For this purpose different types of conservation status (e.g., UNESCO and national heritage) were considered and spatial differences in the sacral historic-cultural monuments (hereafter - HCM) were analyzed through the assessment of their number, modified indices of the sacral objects' concentration, coefficients of localization and educational value, etc, with application of the methods of partial and integral point-based ranking and cluster analysis with respect to the 58 administrative districts of the region. Following the survey of the CRTR where the sacral HCM were found to be the range from average to very good condition, and proceeding from ethnographic-historical context, the region was spatially differentiated into the Roztotsko-Boykivskyy Meso-District on the northwest, the Hutsul Meso-District in the Prykarpattia, and the Bukovynian Ukrainian-speaking and Romanianspeaking micro-districts in the Prypruttia. Among the 6 formed district-status CRTR clusters, 3 of them (27.6\% of the administrative districts of the region) were assessed as the most optimal for the purpose of efficient tourism/excursion activity (hereafter - TEA) and its management, while average geometric indices of all aforesaid coefficients ranged from the above-average (4.10) to the highest (7.59) throughout the whole region. It is suggested to achieve efficient tourism management within the studied territories by way of more active introduction of a series of previously tested pilgrimages and educative-religious tours, as well as through different interstate events of trans-border cooperation. All these would increase the competitiveness of the HCM-oriented tourism industry, be helpful in ascertaining which specifically attractive territories should receive investment, and help integrate the Carpathian Region of Ukraine into the common cultural and tourism space of the EU countries.

Key words: sacral heritage, tourism, rating, cluster, destination, Carpathians

\section{Сакральна спадщина Карпатського регіону та управління іiї ресурсною складовою в туристичній діяльності}

\author{
В.П. Круль ${ }^{1}$ А.А. Вдовічен ${ }^{2}$ Р. М. Гищук², І. П. Добинда ${ }^{1}$
}

${ }^{1}$ Чернівещький національний університет ім. Ю. Федьковича, Украӥна, kroolv@ukr.net

${ }^{2}$ Чернівецький торговельно-економічний інститут KHTEУ, Украӥна, groma2006@gmail.com

\begin{abstract}
Анотація. Карпатський рекреаційно-туристичний регіон (надалі - КРТР) в Україні - це унікальна територія, де представлена сакральна історико-культурна спадщина різних часових періодів: від давньоруського, литовського, османського, австроугорського до польського, румунського, чехословацького та українського. Тому вкрай нагальною є всебічна комплексна оцінка забезпечення та механізми управління сакральною історико-культурною спадщиною (надалі - ІКС) Карпатського туристичнорекреаційного регіону в Україні для інтенсивнішого їхнього залучення до єдиного культурного, туристичного простору та транскордонного співробітництва разом із сусідніми країнами ЄС: Румунією, Словаччиною, Польщею, Угорщиною та Молдовою. Для цього бралися до уваги різні охоронні статуси (спадщина ЮНЕСКО, національний) та просторові відмінності сакральних історико-культурних пам’яток (надалі - ІКП) через оцінку їхньої кількості, модифіковані показники концентрації
\end{abstract}


сакральних об’єктів, коефіцієнти локалізації та пізнавальної цінності, застосовуючи в оцінюванні методи часткової та інтегральної рейтингової бальної оцінки та кластерного аналізу за 58 адміністративними районами регіону. За підсумками наукових вишукувань КРТР забезпеченості сакральними ІКП від пересічної до дуже доброї, виходячи 3 етнографічноісторичного змісту, у просторовому вимірі регіон диференційований на Розтоцько-Бойківський мезорайон на північному заході, Гуцульський мезорайон на Прикарпатті та Буковинський україномовний і румуномовний мікрорайони в Припрутті. 3-поміж 6 сформованих кластерів районного статусу в КРТР 3 (27,6\% адміністративних районів регіону) оцінюються як найоптимальніші стосовно обставини для найрезультативнішої туристично-екскурсійної діяльності (надалі ТЕД) та іiї менеджменту, а їхні пересічно геометричні показники усіх раніше зазначених коефіцієнтів коливаються від вищих за середні $(4,10)$ до найвищих $(7,59)$ значень по всьому досліджуваному регіону. Для ефективного туристичного менеджменту визначених територій пропонується активніше впровадження низки апробованих в регіоні паломницьких та пізнавально-релігійних турів та різних міждержавних заходів транскордонного співробітництва, що дасть змогу підвищити конкурентоспроможність туристичної галузі з використанням сакральних ІКП регіону, визначити його конкретні території інвестування, туристичної привабливості та інтегрувати Карпатський регіон України до єдиного культурного та туристичного поля разом із країнами ЄС.

Ключові слова: сакральна спадщина, туризм, рейтинг, кластер, дестинація, Карпати

\section{Introduction.}

The present-day stage of the development of society clearly presents the problem of the rebirth and preservation of its culture and spirituality, and the sacral objects as key elements of cultural richness and development of religious tourism represent the essential part of the regional HCM. The oblasts that cover the Carpathian Region bordering the EU countries (Romania, Slovakia, Poland) and comprise the common Carpathian Recreation Zone of Ukraine are distinctive for the enormous concentration of sacral tourism objects, which can be explained by the Carpathian Region's long-time experience as part of the AustroHungarian Empire, Poland, Romania and Czechoslovakia (Fig. 1).
Assessment of sacral tourism potential (hereafter - STP) of regional heritage lies in substantiation of its efficient management and the use of its objects in spatial and systemic-structural establishment of the place of specific resource within this or that territory for the purpose of definition of the ways of its subsequent development. Domestic science is represented by almost no studies related to management of tourism of religious objects and provides no parameterized assessment of sacral monuments with application of mathematical methods. The necessity of solution of these questions preconditioned the rationality of our choice as well as predefining its tasks and directions.

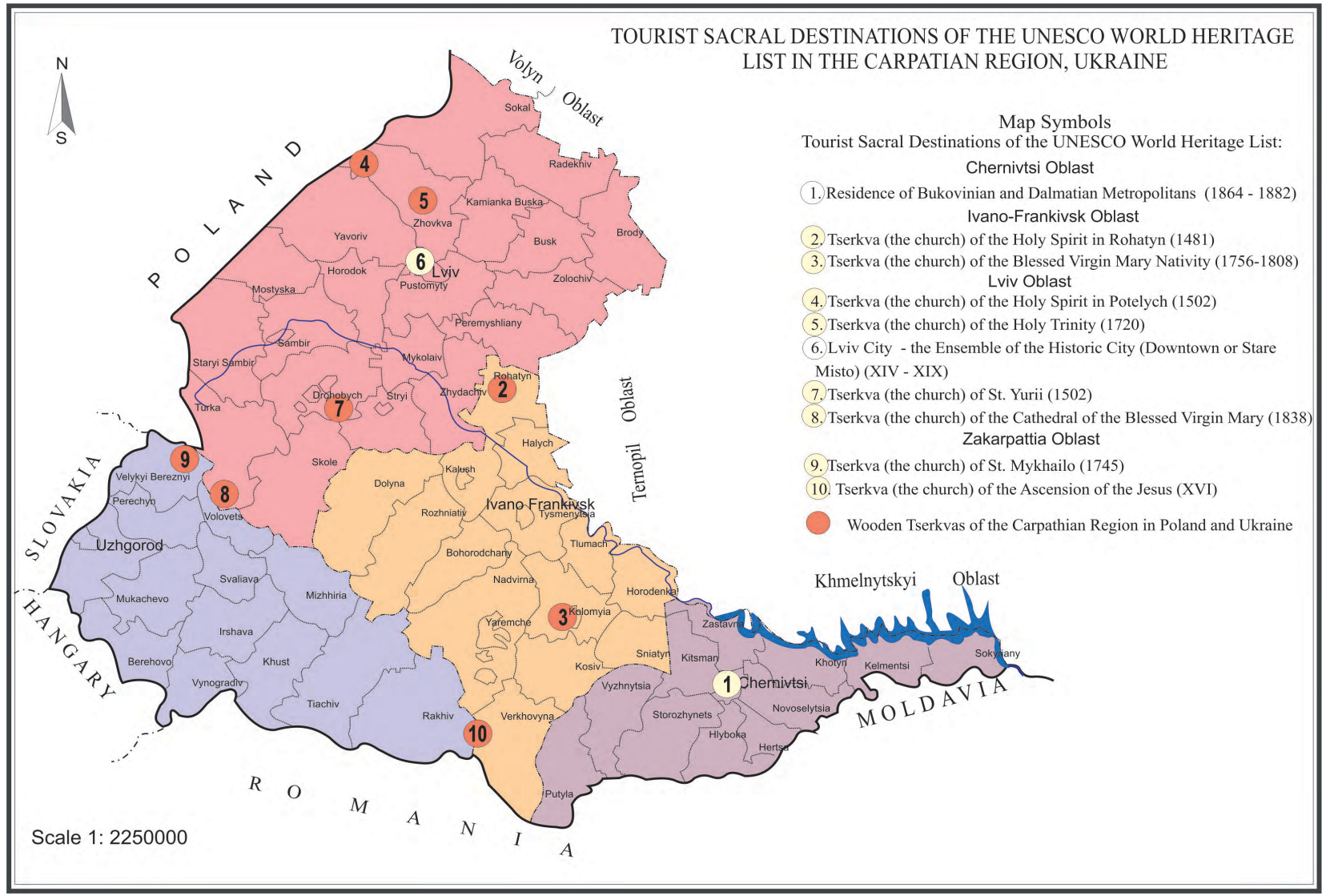

Fig. 1. The Map of Geographical Layout of the Study Area and its Main Sacral HCH of the UNESCO World Heritage List 


\section{The aim of the study.}

The aim of the article is to study and analyze the sacral historic-cultural heritage potential of the Carpathian region and its administrative districts in Ukraine, and to substantiate the expediency of the development and management of tourism activity here based on its sacral clusters.

\section{Review of previous research.}

The spatial structure of STPs in Chernivtsi Oblast's in the Peredkarpattia (Pre-Carpathians) and the Carpathians was the area of scientific interest of I. Kostashchuk and A. Hutsuliak (2014). I. Kostashchuk is also known for his research into theoretical-methodological problems of the religious confessional space of Ukraine and its influence upon social processes (Kostashchuk, 2018, 2019 a). Religious tourism as a subject matter of research is found in the works by $\mathrm{I}$. Dobynda (2014). In particular, she is known for elaboration of sacral tourism routes in the Volyn (Dobynda, 2016). The resource component of Buddhist international and local tourism in China was described in the works by the American and Chinese scientists, Robert Shepherd and $\mathrm{Gu}$ Huimin respectively. The authors came to the conclusion that the pilgrimages in China are rather a religious than a tourism phenomenon and that the rush of tourists to the destination Wutai Shan, China, endangers the uniqueness of the local cultural landscape (Shepherd R. \& Huimin Gu., 2012).

Problematic questions and promising regions for international religious tourism in Ukraine on the basis of HCM of different religions and ethnic groups that may become the objects of interest of international tourists were considered by Yu. Danilyeva (2012). Similar problems within the territory of the Southern Urals were discussed by a group of authors from Bashkotorstan (Khairetdinova et al., 2016), while Belarusian researchers added the question of development of ethnographic tourism (Blishch, 2014). D. Pryimak (2015) focused on the philosophical view on the factors of religious tourism pilgrimage considering it to be a social phenomenon. The resource base possessed by Ukraine for the purpose of development of pilgrimage and excursion forms of tourism was analyzed by I. Lytvyn (2014), while its regional aspect was considered on the example of Prykarpattia by V. Shykerynets (2012). The pilgrimage resource base from Nepal to Australia was characterized by du Cros H. and Johnston C. (2002), while religious journeys as a form of tourism and pilgrimage were characterised by Olsen D. and Timothy D. (2006).

The essence and the principles of the logistic approach to efficient organization of tourism space on the example of religious tourism, and the analysis of the structure and the components of the same were discussed in the study by I. Smyrnov. The author's assessment of the logistics in this segment of tourism services resulted in the development of measures to help preserve sacral resources (objects) from excessive use by tourism (Smirnov, 2015). The importance of solution of the problem of preservation of hieratic sacral resources possessed by indigenous people of Southern Siberia through tourism and use of these resources in different tourism routes was actualized in the scientific community by E. Chaykina. The results of her work were suggested to be used for stimulation of tourism business in the Altai (Chaikina, 2017).

S. Panchenko's research is perhaps the only study devoted to management of religious monuments tourism in Ukraine. The author emphasized the huge potential of religious tourism in this country, which is yet not appropriately made use of. This is why the arrangement of favourable conditions for high-quality religious tourism involving domestic and foreign tourists requires a more active state policy and involvement of investments into the tourism industry of Ukraine (Panchenko, 2019). Problems of management of sacral resources in the tourism industry and the strategy of their development in the Podillia (Ukraine) were highlighted by Hordyskyi Y. and Manko A. (2012). Present-day resources of cultural heritage, its different statuses, assessment and importance, as well as the system of its management were the basis of the contribution by Taylor K. (2004). Positive experience of management of stable tourism in religious and holy places of local communities in California and Thailand was disclosed in publication by the American scholars Levi D. and Kocher S. (2009).

A thorough search into management of religious tourism is found in the work presented in the collective monograph entitled Religious Tourism and Pilgrimage Management. In particular, the authors focus on concepts of religious tourism and its management, motivations behind the phenomenon of pilgrims' migrations, examples of international religious tourism case studies in South-East Asia, Israel, Ireland, Northern Portugal, Argentina, Lebanon, and Malta (Rai \& Griffin, 2015).

Present-day problems of managing 166 objects of world religious heritage were analyzed by Myra Shackley on the example of cultural tourism. She considered different religious traditions of predominantly Christian culture (51\%) in the Northern hemisphere, as well as the questions of balanced preservation of sacral objects for the purpose of improvement of tourism service (Shackley, 2001). 
To summarize, the studies of sacral and religious monuments in the Ukrainian regions generally emphasize the description of the resource component, while questions of HCM management for balanced improvement of tourism service are considered superficially, with no regional specifications or insights into adjoining countries and their parts. It is therefore for the first time in Ukraine that such studies of spatial content with application of mathematical multifactor methods are conducted for the CRTR as an essential part of the large Carpathian Tourism/Recreation Zone that also covers territories in Poland, Slovakia and Romania. The major task of this article lies in assessment of tourism sacral potential in Ukrainian administrative oblasts covered by the CRTR for the purpose of strengthening the efficiency of its financial management in conditions of decentralization of economics that started in 2014, and subsequent formation of tourism attractiveness of the country's new financial centers, i.e., territorial communities. A cartographic model of total ranking positions of each administrative oblast with respect to four assessed components shall be one of the results of this work. Finally, it will allow us to outline the major territorial units possessing the greatest, average and the least potentials of a sacral HCH's integral value. We cannot but accentuate that the study results and the methods of counting the ranking positions of the administrative-territorial units with respect to total value of their $\mathrm{HCH}$ sacral objects can be made use of by other local bodies of self-government and respective institutions for the purpose of efficient management of their tourism-excursion activity (hereafter - TEA). Besides, they can also be helpful in similar studies of the Carpathian Tourism/Recreation Zone pertaining to Poland, Slovakia and Romania.

\section{Methodology.}

The research on $\mathrm{HCH}$ is based on several criteria where the majority of researchers consider either their material component or recreation (recreation/tourism) resources. The point-based assessment of sacral $\mathrm{HCH}$ as tourism destinations was suggested by $\mathrm{O}$. Beidyk (2001) and T. Bozhuk (2008). I. Kostashchuk, having combined methodological developments of the aforesaid authors, retains point-based assessment, together with O. Lyubitseva (2009), in his own way. The researcher suggests such assessment criteria as the object's geographical disposition (type of settlement and the number of its inhabitants, transport accessibility, etc.), its compositional value, presence of sacred places, architectural appearance and value, the infrastructure of the object itself, historical significance, church (confessional) significance, attractiveness and accessibility for visiting, availability of information resources, and the object's present-day state. On the whole, each criterion can be awarded a maximum of 5 points, though this value may increase to 10 if the above-suggested coefficients are applicable (Kostashchuk, 2017, 2019 b). However, even with such detailed methodological analysis, there remains a role for subjective assessment through verbal explanation in the absence of clear quantitative/qualitative parameterization and with no possibility of application of specific mathematical methods of research.

The study of the region's sacral heritage ( the Carpathian region, Ukraine) was carried out using the method of K. Polyvach, which was declared by her in her dissertation research and monographs, in which she offers comprehensive geographic methods for an integral assessment of the cultural heritage of a region or regions (Polyvach, 2007). To ensure the correctness of the comparison of regions, in addition to general statistical indicators of the number of sacral tourist objects represented in the State Register of Monuments of Ukraine, the authors also used regional coefficients: the modified coefficient of concentration of tourist destinations and the localization coefficient of objects, calculated using geographical methods of research. Therefore, in order to determine the status capacity of differently weighted religious sites-destinations, account was taken not only of their number, but also their conservation status as an integral object of tourist and excursion activity, proceeding from the coefficients proposed in formula 1 (Krool et al., 2018):

$$
C_{H C P}(s)=\sum k \times \mathrm{x} 1+k \times \mathrm{x} 2+k \times \mathrm{x} 3+k \times \mathrm{x} 4
$$

where: $C_{H C P}(s)$ is the status capacity of historical and cultural significant sites (including sacral) of different weights (values); $k$ is the coefficient of the "status weight" of the historical and cultural significant sites, where 1.2 is obtained by the significant sites of international (UNESCO heritage) value, 1.0 by the sites of national importance, 0.9 by the sites of state importance, 0.75 by the sites of local significance; and $x 1, x 2, x 3, x 4$ the number of historically and culturally significant sites, respectively, of international, national, state and local status. The component part of the $\mathrm{C}_{\mathrm{HCP}}(\mathrm{s})$ and the same formula for the sacral $\mathrm{HCM}$ is the coefficient of conservation status $\left(\mathrm{C}_{\mathrm{c.s}}\right)$.

Two other criteria (modified indicator (coefficient) of concentration of sacral monuments concentration and the localization of sacral HCM) were counted according to K. Polyvach's formula (Polyvach, 2012).

The second factor component of the partial rating of 
the regional historical and cultural heritage in the study is a modified indicator (coefficient) of concentration of tourist destinations (MIs.m.c.). It takes into account both the number of sacral historical and cultural destinations, the total area on which they are located, and the tourists who visited them for a certain period of time, usually a year. The methodology of its calculation is presented in K. Polyvach using the formula (Polyvach, 2007):

$$
W=V / \ln B
$$

where: $W$ - modified index (coefficient) of concentration of tourist destinations; $V$-absolute indicator of the number of objects of the sacred heritage in the region; $S$ - area of the studied regions; $P$ - population of the region; $\mathrm{B}-\sqrt{ } \mathrm{SP}$.

The third factor component of the partial rating assessment of the regional heritage is the localization of the sacral HCM. This factor takes into account the specific weight of the territory by the number of sacral destinations and the specific weight of the territory by area. The order of its calculation is presented in the formula "3" (Polyvach, 2012):

$$
\mathrm{K}_{l o c}=C h / C s
$$

where: $\mathrm{Ch}$ - specific weight of the region by the number of objects of historical and cultural heritage; $C s$ - the region's share by area.

The component part of the $\mathrm{K}_{\mathrm{loc}}$ and the same formula for sacral HCM is the index of localization of sacral objects $\left(\mathrm{L}_{\text {s.o. }}\right)$.

And, finally, the fourth criterion, i.e., the coefficient of educational value of sacral tourism destinations $\left(\mathrm{C}_{\text {e.v. }}\right)$ was counted as the proportion between the total points gained in the result of assessment of the sacral HCR of a specific settlement or locality and the maximum possible points provided in the assessment scale by (Kravtsiv et al., 1999):

$$
C_{e . v}=A / A_{\max }
$$

where: A is a sum of points of educational value of historic-cultural tourism resources in a specific settlement, territory (block); $\mathrm{A}_{\max }$ - maximum possible points according to point-based assessment scale (Kravtsiv et al., 1999).

Consequently, the total rank value of all four factor components and their partial assessments of the region's sacred and religious heritage gives, as a result, an overall score in points (according to the rating) that a region has received. It is important that this evaluation has an inverse relationship (lower scores correspond to better and enhanced potentials) for effective and promising use in domestic and international tourism and excursion activities, as well as within the framework of EU associate membership and wider cross-border cooperation between Ukraine, Romania, Poland, Slovakia and other countries of the entire Carpathian recreational and tourist zone.

\section{Research results and discussion.}

Historic-cultural resources (hereafter - HCR) is the totality of monuments of material and spiritual culture created in the process of historic development of a specific territory that now have become objects of tourists' interest. The HCR include educational, event-related, ethnographic and biographic-social resources (Malska \& Antoniuk, 2008). Hence, the HCH represents the totality of objects of cultural heritage inherited by mankind from previous generations. Sacral resources of religious pilgrimage and educative/informative content with respect to the material and spiritual culture heritage within a specific territory comprise an essential part of the aforesaid resources.

The CRTR of Ukraine covers four administrative oblasts consisting of 58 administrative districts, and features 774 sacral national-status HCM and those included in the UNESCO World Heritage List. The monuments' assessment showed that 29 administrative districts unevenly located in all oblasts of the region, namely, Lviv, Ivano-Frankivsk, Zakarpattia and Chernivtsi administrative oblasts, manifest the values of the coefficient of conservation status $\left(\mathrm{C}_{\mathrm{c.s}}\right)$ which are higher than the mean values of the same within the region (8.7) (see Table 1). The greatest share $(62 \%)$ out of their totality is concentrated in Lviv Oblast - 479 HCM, 16\% - in Ivano-Frankivsk (125 HCM), 15\% in Zakarpattia (114 $\mathrm{HCM}$ ), and $7 \%$ in Chernivtsi oblasts (56 HCM). With respect to number of HCM that exceeds the average values for the Carpathians, $2 / 3$ of them are found on the territory of Lviv Oblast (418 HCM), 18\% - Zakarpattia Oblast (112 HCM), 13\% - Ivano-Frankivsk Oblast (83 HCM), and 3\% - Chernivtsi Oblast (22 HCM).

According to the total score of the sacred heritage objects by the administrative units of the entire Carpathian region and the methodology for calculating the modified concentration indicators, the localization coefficient of tourist and religious excursion destinations and coefficient of their cognitive value, we calculated the total ratings of the administrative-territorial units for each of the four indicators (see Table 1).

The values exceeding those of the modified index of sacral monuments concentration $\left(\mathrm{MI}_{\text {s.m.c. }}\right.$ ) in the Carpathian Region (10.48) were observed in its 29 territorial units, where 17 or $58.6 \%$ account for administrative districts of Lviv Oblast, 5 and 5 (17.2\% and 17.2\% each) - Ivano-Frankivsk and Zakarpattia oblasts, and 2 (6.9\%) - of Chernivtsi Oblast. Absolute leadership in respect of monuments' concentration is taken by the City of Lviv, 
Table 1. The total rating of sacral HCM of national status and UNESCO World Heritage List in the administrative districts of the Carpathian region, Ukraine

\begin{tabular}{|c|c|c|c|c|c|c|c|c|c|}
\hline Administrative districts & 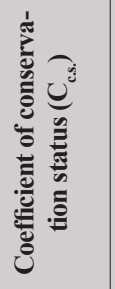 & 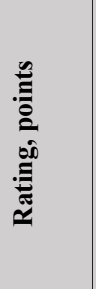 & 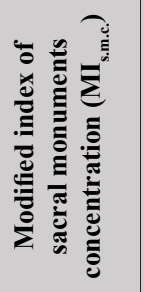 & 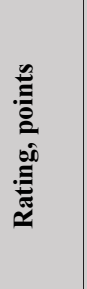 & 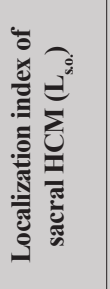 & 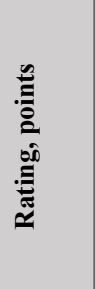 & 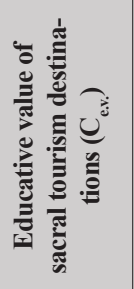 & 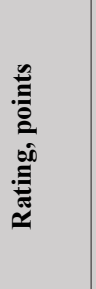 & 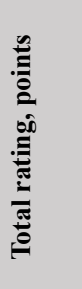 \\
\hline Berehovo & 6.0 & 41.0 & 7.97 & 40 & 0.620 & 34 & 0.545 & 56.0 & 171.0 \\
\hline Bohorodchany & 7.0 & 36.5 & 8.03 & 39 & 0.575 & 37 & 0.583 & 54.0 & 166.5 \\
\hline Brody & 18.0 & 14.0 & 19.69 & 16 & 1.019 & 19 & 0.667 & 50.0 & 99.0 \\
\hline Busk & 21.0 & 12.5 & 26.30 & 11 & 1.610 & 11 & 0.913 & 35.0 & 69.5 \\
\hline Chernivtsi city & 7.2 & 33.5 & 8.97 & 35 & 3.089 & 4 & 0.600 & 52.5 & 125.0 \\
\hline Drohobych & 17.2 & 15.0 & 17.56 & 19 & 0.925 & 23 & 0.956 & 30.0 & 87.0 \\
\hline Halych & 6.0 & 41.0 & 8.07 & 38 & 0.545 & 40 & 0.857 & 39.0 & 158.0 \\
\hline Hertsa & 12.0 & 21.0 & 23.51 & 12 & 2.493 & 7 & 1.000 & 17.0 & 57.0 \\
\hline Hlyboka & 5.0 & 44.5 & 5.89 & 45 & 0.488 & 42 & 1.000 & 17.0 & 148.5 \\
\hline Horodenka & 3.0 & 51.5 & 3.78 & 50 & 0.264 & 50 & 0.600 & 52.5 & 204.0 \\
\hline Horodok & 23.0 & 10.5 & 27.08 & 10 & 2.077 & 9 & 1.000 & 17.0 & 46.5 \\
\hline Irshava & 8.0 & 31.0 & 8.09 & 37 & 0.556 & 39 & 0.889 & 36.0 & 143.0 \\
\hline Ivano-Frankivsk city & 4.0 & 47.5 & 6.17 & 43 & 3.136 & 3 & 0.800 & 45.0 & 138.5 \\
\hline Kamianka Buska & 11.0 & 23.5 & 12.96 & 25 & 0.833 & 27 & 1.000 & 17.0 & 92.5 \\
\hline Khotyn & 1.0 & 57.0 & 1.22 & 58 & 0.092 & 58 & 1.000 & 17.0 & 190.0 \\
\hline Khust & 11.0 & 23.5 & 11.17 & 28 & 0.741 & 31 & 0.917 & 34.0 & 116.5 \\
\hline Kitsman & 10.0 & 27.5 & 12.34 & 26 & 1.081 & 18 & 1.000 & 17.0 & 88.5 \\
\hline Kolomyia & 7.2 & 33.5 & 7.19 & 42 & 0.473 & 43 & 1.200 & 1.0 & 119.5 \\
\hline Kosiv & 40.0 & 4.0 & 41.36 & 4 & 2.663 & 6 & 0.870 & 38.0 & 52.0 \\
\hline Lviv city & 85.6 & 1.0 & 153.1 & 1 & 308.7 & 1 & 0.251 & 58.0 & 61.0 \\
\hline Mizhhiria & 27.0 & 8.5 & 30.96 & 6 & 1.520 & 13 & 1.000 & 17.0 & 44.5 \\
\hline Mostyska & 8.0 & 31.0 & 9.53 & 31 & 0.621 & 33 & 1.000 & 17.0 & 112.0 \\
\hline Mukachevo & 6.0 & 41.0 & 6.00 & 44 & 0.395 & 45 & 0.667 & 50.0 & 180.0 \\
\hline Mykolaiv & 6.0 & 41.0 & 7.37 & 41 & 0.584 & 36 & 1.000 & 17.0 & 135.0 \\
\hline Nadvirna & 12.0 & 21.0 & 11.04 & 29 & 0.609 & 35 & 0.923 & 33.0 & 118.0 \\
\hline Novoselytsia & 2.0 & 53.5 & 2.28 & 54 & 0.178 & 53 & 1.000 & 17.0 & 177.5 \\
\hline Perechyn & 2.0 & 53.5 & 3.07 & 52 & 0.208 & 52 & 1.000 & 17.0 & 174.5 \\
\hline Peremyshliany & 13.0 & 19.0 & 16.76 & 20 & 0.930 & 22 & 0.813 & 44.0 & 105.0 \\
\hline Pustomyty & 43.0 & 3.0 & 42.46 & 3 & 2.962 & 5 & 0.843 & 41.0 & 52.0 \\
\hline Putyla & 7.0 & 57.0 & 10.25 & 30 & 0.520 & 41 & 1.000 & 17.0 & 145.0 \\
\hline Radekhiv & 12.0 & 21.0 & 13.86 & 23 & 0.689 & 32 & 1.000 & 17.0 & 93.0 \\
\hline Rakhiv & 10.2 & 25.5 & 9.09 & 34 & 0.354 & 46 & 1.020 & 2.0 & 107.5 \\
\hline Rohatyn & 15.2 & 17.0 & 20.18 & 14 & 1.224 & 16 & 0.691 & 47.0 & 94.0 \\
\hline Sambir & 14.0 & 18.0 & 15.56 & 21 & 0.984 & 20 & 0.933 & 32.0 & 91.0 \\
\hline Skole & 35.0 & 5.0 & 38.00 & 5 & 1.563 & 12 & 1.000 & 17.0 & 39.0 \\
\hline Sniatyn & 4.0 & 47.5 & 5.05 & 47 & 0.438 & 44 & 1.000 & 17.0 & 155.5 \\
\hline Sokal & 21.0 & 12.5 & 19.47 & 17 & 0.878 & 24 & 0.750 & 46.0 & 99.5 \\
\hline Sokyriany & 1.0 & 57.0 & 1.38 & 56 & 0.099 & 56 & 1.000 & 17.0 & 186.0 \\
\hline Staryi Sambir & 27.0 & 8.5 & 27.26 & 9 & 1.424 & 15 & 0.844 & 40.0 & 72.5 \\
\hline Storozhynets & 2.0 & 53.5 & 1.93 & 55 & 0.113 & 55 & 1.000 & 17.0 & 180.5 \\
\hline Stryi & 7.0 & 36.5 & 8.26 & 36 & 0.569 & 38 & 1.000 & 17.0 & 127.5 \\
\hline Svaliava & 1.0 & 57.0 & 1.28 & 57 & 0.098 & 57 & 1.000 & 17.0 & 188.0 \\
\hline Tiachiv & 6.0 & 41.0 & 4.79 & 48 & 0.217 & 51 & 1.000 & 17.0 & 157.0 \\
\hline Turka & 27.2 & 7.0 & 30.75 & 7 & 1.500 & 14 & 1.007 & 4.0 & 32.0 \\
\hline Tysmenytsia & 3.0 & 50.5 & 3.37 & 51 & 0.269 & 49 & 1.000 & 17.0 & 167.5 \\
\hline Uzhgorod & 4.0 & 47.5 & 4.46 & 49 & 0.302 & 48 & 0.667 & 50.0 & 194.5 \\
\hline Uzhgorod city & 4.0 & 47.5 & 12.07 & 27 & 6.564 & 2 & 0.500 & 57.0 & 133.5 \\
\hline Velykyi Bereznyi & 10.2 & 25.5 & 15.36 & 22 & 0.828 & 28 & 1.020 & 2.5 & 78.0 \\
\hline Verhovyna & 16.0 & 16.0 & 20.25 & 13 & 0.834 & 26 & 0.941 & 31.0 & 86.0 \\
\hline Volovets & 10.0 & 27.5 & 17.84 & 18 & 1.207 & 17 & 1.000 & 17.0 & 79.5 \\
\hline Vynogradiv & 9.0 & 29.0 & 9.34 & 33 & 0.848 & 25 & 0.563 & 55.0 & 142.0 \\
\hline Vyznytsia & 2.0 & 53.5 & 2.35 & 53 & 0.145 & 54 & 1.000 & 17.0 & 177.5 \\
\hline Yaremche & 8.0 & 31.0 & 13.55 & 24 & 0.801 & 29 & 1.000 & 17.0 & 101.0 \\
\hline Yavoriv & 23.0 & 10.5 & 20.07 & 15 & 0.975 & 21 & 1.000 & 17.0 & 63.5 \\
\hline Zastavna & 7.0 & 36.5 & 9.46 & 32 & 0.742 & 30 & 0.875 & 37.0 & 135.5 \\
\hline Zhovkva & 47.4 & 2.0 & 44.07 & 2 & 2.403 & 8 & 0.668 & 48.0 & 60.0 \\
\hline Zhydachiv & 5.0 & 44.5 & 5.50 & 46 & 0.330 & 47 & 0.833 & 42.0 & 179.5 \\
\hline Zolochiv & 28.0 & 6.0 & 29.77 & 8 & 1.671 & 10 & 0.824 & 43.0 & 67.0 \\
\hline Average value in region & 8.7 & - & 10.48 & - & 0.775 & - & 0.856 & - & 108.0 \\
\hline
\end{tabular}

Source: authors of paper 
where the said concentration of sacral tourism and excursion objects exceeds by 3.5 times the values manifested by the runner- up Zhovkva District (44.07). It should be noted that the first ten places with respect to values of the modified index are in its absolute majority represented by administrative districts of Lviv Oblast, with the minor exceptions of Kosiv District (41.36, IvanoFrankivsk Oblast) and Mizhhirya District (30.96, Zakarpattia Oblast). Though not so markedly, administrative districts of Lviv Oblast have taken the lead in the second ten, with a few more inclusions of two administrative districts of Ivano-Frankivsk Oblast (Verkhovyna and Rohatyn), one district of Zakarpattia Oblast (Volovets), and one - of Chernivtsi Oblast (Hertsa). It is only in the third ten that Lviv Oblast's leadership comes to naught despite the fact that the third ranking ten is headed by Sambir District of Lviv Oblast (15.56) and represented by two more districts of the same oblast (Radekhiv and Kamianka-Buzka). The third ten is distinctive for the fact of being represented by administrative units of all other oblasts of the Carpathian Region, that is, Zakarpattia Oblast (Velykyi Bereznyi District, Khust District and Uzhgorod City), Ivano-Frankivsk Oblast (Nadvirna District and Yaremche City Council), and Chernivtsi Oblast (Kitsman District and Putyla District).

For a more detailed explanation of the presence and location of sacral sites in the Carpathian region, it is worthwhile analyzing the distribution of the localization coefficients for sacral heritage sites. In this case, the optimal value should approach 1 , since here the ratio of the shares of sacral objects of the specific weight of the areas on which they are represented is taken into account.

In this context, the four leading places are taken by the oblast centers where localization of sacral HCM $\left(\mathrm{L}_{\mathrm{s} . \mathrm{o}}\right)$ predefines the most favourable territorial component which is complemented by transport accessibility. Hence, the hierarchy between the oblast capital cities has formed as follows: Lviv (308.7), Uzhgorod (6.564), Ivano-Frankivsk (3.136), and Chernivtsi (3.089). On the whole, the optimal structure (over 1.000) is possessed by 15 more administrative-territorial units, 9 of which (Pustomyty, Zhovkva, Horodok, Zolochiv, Busk, Skole, Turka, Staryi Sambir, Brody) refer to Lviv Oblast $(52.6 \%)$, and two districts each represent the remaining oblasts (Kosiv and Rohatyn, Hertsa and Kitsman, Mizhhiria and Volovets administrative districts of Ivano-Frankivsk, Chernivtsi and Zakarpattia administrative oblasts respectively). It should also be noted that 10 more administrative-territorial units within the region of this study that manifest not so favourable concentrations of sacral HCM (coefficient of localization is less than 1), nonetheless show the above-average values if compared to all remaining administrative districts. The majority of these districts once again are located on the territory of Lviv Oblast (Brody, Sambir, Yavoriv, Peremyshliany, Drohobych, Sokal) with 2 districts each located in Ivano-Frankivsk (Verkhovyna and the lands of the Yaremche City Council) and Zakarpattia (Vynogradiv and Velykyi Bereznyi) oblasts with no representation of Chernivtsi Oblast.

The districts in the Carpathians referred to as unique with their specific sacral HCM and thematic TEA specialization are only those where the coefficient of educative value $\left(\mathrm{C}_{\text {e.v. }}\right)$ for such territories is $\geq 1$. There are now 29 such districts almost evenly distributed in all oblasts save for Ivano-Frankivsk Oblast. 9 districts each, or $31.0 \%$ represent Lviv and Chernivtsi oblasts, and $24.1 \%$ - Zakarpattia Oblast. A weighty though not dominant share of sacral HCM in the region predefines the attractiveness of these resources in the territories where $\mathrm{C}_{\mathrm{e} . \mathrm{.}}<1$ but still exceeds the average value $(0.856)$ in the Carpathian Region (8 territorial units). Such situation is characteristic for $37.5 \%$ of the districts of Ivano-Frankivsk Oblast (Nadvirna, Kosiv and Halych districts), while it is the least characteristic in Chernivtsi Oblast (only Zastavna District).

Thus, the dominance or trailing position of the districts in the four parameters assessed above predefined their respective ranking position with respect to each of the parameters, as well as allowing the establishment of their total values and ranking positions to be expressed in points. In these cases, a sufficient reserve in the districts or their larger territorial formations follows from the least ranking points, thus outlining them into a space possessing the best sacral-resource component and preconditions of their efficient management within the frame of the TEA.

Now the totality of ranking points in the Carpathian Region ranges from 33 (Turka District, Lviv Oblast) to 204 (Horodenka District, Ivano-Frankivsk Oblast), and the average value for all 58 administrative-territorial units is 107 points. These figures gave grounds to combine the total ranking points of administrative districts and other territories into 7 groups, three of which are referred to as having an adequate (81-100 points), good (61-80 points) and very good (up to 60 points), and three more as insufficient (121-140 points), poor (141-160 points) and the poorest (161 and more points) reserve of sacral HCM as compared to the group with average reserve (101-120 points) of the same in the Carpathian Region.

As follows from the assessed parameters and their total ranking points, very good and good HCM reserves and preconditions for the TEA-related efficient management are found in 14 administrative districts and in the City of Lviv. Their core area $(66.7 \%)$ is located on the territory of Lviv Oblast from Roztochchia to Peredkarpattia in Boykivshchyna, while the districts have on a 
$50 / 50$ basis a good and very good HCM reserve. A very good sacral HCM reserve is also found in the Zakarpattia's Boykivshchyna (Mizhhirya District -44.5 points), Halychski Hutsulshchyna (Kosiv Distriuct, IvanoFrankivsk Oblast - 52 points), and in Chernivtsi Oblast (Hertsa District - 57 points). A good HCM reserve is observed in $71.4 \%$ of districts of Lviv Oblast, which supplement the territorial massif of its Roztotsko-Boykivska part together with Velykyi Bereznyi (78 points) and Volovets districts (79.5 points) from Boykivshchyna in the Zakapattia.

9 more administrative districts of the region show a sufficient sacral HCM reserve and practically the same potentiality for their efficient management within the TEA frame. As in the previous situation, Lviv Oblast dominates with $2 / 3$ of the sufficient reserve being represented by its districts from Roztochchia to Peredkarpattia in Boykivshchyna, together with the adjoining Rohatyn District (94 points). One more unit manifesting sufficient sacral HCM reserve, namely, Verkhovyna District (86 points), adjoins the Hutsul Meso-Region together with the aforementioned Kosiv District. Kitsman District (88.5 points) of Chernivtsi Oblast is outlined as a separate territorial element.

Average reserve of sacral HCM is characteristic for the territory of the Yaremche City Council and 6 administrative districts, almost $29 \%$ of which are located in Lviv Oblast (Mostyska and Peremyshliany districts). Hutsul Meso-District covers the Rakhiv District (Zakarpattia Oblast), the town of Yaremche and the southern portion of Nadvirna District (Ivano-Frankivsk Oblast) (from 101 to 118 points). These are supplemented by Kolomyia District (119.5 points) in Pokuttia. Khust District (Zakarpattia Oblast, 115.5 points) represents the buffer locality between the mountain territory of the Carpathians and the Zakarpattia Lowland, and shows a below average sacral HCM reserve.

The other massifs of insufficient, poor and very poor HCM reserve in the Carpathian Macro-Region are found in the far east of Northern Bessarabia comprising Novoselytsia, Sokyriany and Khotyn districts (176.5189 points), the Bukovynian portion of Chernivtsi Oblast (Vyzhnytsia and Storozhynets districts, 176.5 and 179.5 points respectively), in Pokuttia (Tysmenytsia and Horodenka districts, 166.5 and 204 points respectively), and in part of Boykivshchyna (Bohorodchany District, 166.5 points) of Ivano-Frankivsk Oblast. Besides, the far south west of the Carpathian Region within the borders of the Zakarpattia features the essential territorial massif of very poor sacral HCM reserve, formed of Berehovo, Perechyn, Mukachevo, Svaliava and Uzhgorod administrative districts, which show 170-193.5 points.

Thus, according to point-based division into very good, good, sufficient and average sacral HCM reserve, the CRTR features the Roztotsko-Boykivskyy MesoDistrict in the northwest, Hutsul Meso-District in the Prykarpattia and the Bukovynian Ukrainian-speaking and Romanian-speaking micro-districts in the Prypruttia. The first-mentioned territory is the largest since it covers 22 administrative districts and Lviv City. The second is represented by 6 administrative units, while the Ukrainian-speaking and Romanian-speaking $\mathrm{Bu}-$ kovynian micro-districts are quantitatively the smallest territory, since they are formed of only 1 district each.

The method of cluster analysis has become an appropriate extension in our search into still more concentrated disclosure of spatial elements of different hierarchical levels for the purpose of the efficient TEA-related sacral HCM management. Having applied the Statistcis_10, we analyzed four parameterized massifs of statistical data for each of 58 districts within the Carpathian Region. The most optimal and vivid combinations of regional sacral HCM can be observed in 6 clusters when the complete linkage method, Manhattan Matrix, Step 19 are applied (see Fig. 2). These combinations should become the basis for common managerial solutions for better TEA-related sacral HCM-based development. The situation with the city Lviv is specific, since its manifested parameters and closeness of links are essentially different from those of the rest and cannot therefore be combined with any of the remaining clusters since it requires its own unique strategy of sacral HCM management.

The first district cluster includes 12 administrative districts and 2 oblast capital cities, or $24.6 \%$ of their totality within the studied region located within the 4 administrative oblasts: Berehovo, Halych, Mykolaiv, Bohorodchany, Stryi, Irshava, Kolomyia, Mostyska, Putyla, Zastavna, Chernivtsi City, Rakhiv, Vynohradiv, and Uzhgorod City (Administrative - Territorial Cluster Composition, see Fig. 2). The cluster is characteristic for the poorest preconditions for TEA-related sacral HCMbased development since it manifests one of the lowest values of the coefficients of conservation status, localization of sacral objects and modified index of sacral objects concentration $\left(5^{\text {th }}\right.$ position with respect to each coefficient) and educative value ( $6^{\text {th }}$ position) (Table 2$)$. We should also note that the range of difference in the values was, in particular, 4-10.2 for $\mathrm{C}_{\mathrm{cs}}$ (the difference between its maximal and minimal values reached 6.2); 0.354-6.564 for $\mathrm{L}_{\text {s.o. }}(6.21), 0.5-1.2$ for $\mathrm{C}_{\text {e.v. }}(0.7)$, and 7.19-12.07 for $\mathrm{MI}_{\text {s.m.c. }}^{\text {s.o. }}$ (4.88).

Quantitatively, the second district cluster is the largest since it combines 16 administrative units: Hlyboka, Zhydachiv, Mukachevo, Tiachiv, Horodenka, Tysmenytsia, Sniatyn, Uzhgorod, Khotyn, Svaliava, Sokyriany, Novoselytsia, Vyzhnytsia, Storozhynets, Perechyn districts and the Ivano-Frankivsk City. Administrative- 


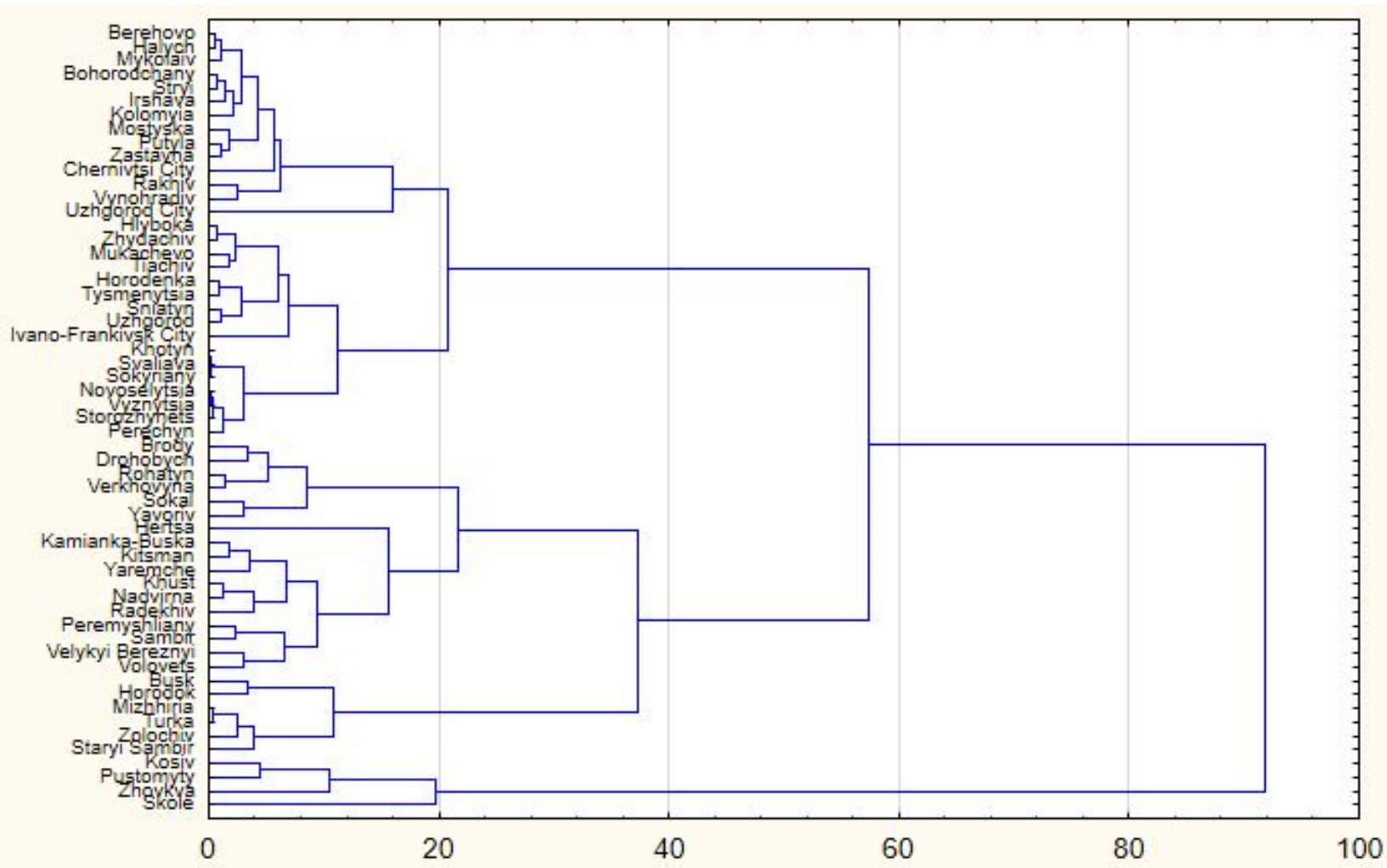

Fig. 2. The Administrative and Territorial Cluster Composition of Sacral HCM of National Status and UNESCO World Heritage List in the Carpathian region, Ukraine (Source: authors of paper)

territorial units within this cluster manifest the poorest average $\mathrm{C}_{\mathrm{c.s} .}, \mathrm{MI}_{\text {s.m.c. }}$ and $\mathrm{L}_{\mathrm{s} . \mathrm{o}}$ values (all of them take $6^{\text {th }}$ place), thus confirming the fact of the most unfavourable TEA-related development preconditions. Such conclusion is not even shattered by the value of $\mathrm{C}_{\text {e. }}$ according to which territorial components there won $3^{\text {rd }}$ positions. The coefficients within this cluster ranged as follows: 5 for $\mathrm{C}_{\text {c.s. }}, 4.95$ for $\mathrm{MI}_{\text {s.m.c. }}, 3.04$ for $\mathrm{MI}_{\text {s.m.c. }}$ and 0.4 for $\mathrm{C}_{\text {e.v. }}$.

Nearly the best preconditions for TEA-related sacral HCM-oriented development have formed in territorial units of the third district cluster. In particular, with respect to manifested average geometrical values of $\mathrm{C}_{\mathrm{c} . \mathrm{s}}$, $\mathrm{MI}_{\text {s.m.c. }}$ and $\mathrm{L}_{\text {s.o. }}$ they took $3^{\text {rd }}$ ranking positions. The value of the $\mathrm{C}_{\text {ev }}$ is the only exception (territorial units have won only the last but one ( $\left.5^{\text {th }}\right)$ position). Still, it can be safely asserted that rather acceptable TEA-related conditions are observed in 6 administrative districts $(10.5 \%$ out of the totality), namely, Brody, Drohobych, Rohatyn, Verkhovyna, Sokal and Yavoriv. Besides, the difference between the maximal and minimal coefficient values is greater than that in two previous clusters only for the $\mathrm{C}_{\mathrm{cs}}=7$ (16-23), while it is essentially smaller for three remaining coefficients: $\mathrm{MI}_{\text {s.m.c. }}=2.69(17.56-20.25), \mathrm{L}_{\text {s.o. }}$ $=0.39(0.834-1.224)$, and $\mathrm{C}_{\text {e.v. }}=0.33(0.67-1)$.

Satisfactory TEA-related figures are observed in 10 districts and 1 town of oblast subordination combined into the fourth district cluster, namely, Hertsa, Kamianka-Buzka, Khust, Kitsman, Nadvirna, Radekhiv, Pere- myshliany, Sambir, Bereznyi, Volovets and the town of Yaremche (19.3\% out of the totality). This conclusion is confirmed by the $4^{\text {th }}$ ranking positions of average coefficients that characterize the spread of sacral HCM, i.e., $\mathrm{C}_{\text {c.s. }}, \mathrm{MI}_{\text {s.m.c. }}$ and $\mathrm{L}_{\text {s.o. }}$. And it is only the value of the $\mathrm{C}_{\text {e.v. }}$ that puts the administrative-territorial formations of the fourth cluster in the $1^{\text {st }}$ position. However, in our opinion, the aforesaid value cannot significantly affect TEArelated preconditions within this territorial combination, and, after all, this becomes clear from the essential difference between the maximal and minimal sacral HCMrelated values.

Thus, the said difference with respect to $\mathrm{C}_{\mathrm{cs.}}$ was the least if compared to other territorial clusters making $3\left(10-13,6^{\text {th }}\right.$ position), and the largest with respect to $\mathrm{MI}_{\text {s.m.c. }}$ making 12.47 (11.04-23.51, $1^{\text {st }}$ position).

Nearly the best preconditions for TEA-related sacral HCM-oriented development have formed in 6 administrative districts which represent within the CRTR the fifth combination of clusters, namely, Busk, Horodok, Mizhhirya, Staryi Sambir, Turka and Zolochiv. The presence and concentration of sacral HCM there is confirmed by consistently high average geometric values of $\mathrm{C}_{\text {c.s. }}, \mathrm{MI}_{\text {s.m.c. }}, \mathrm{L}_{\text {s.o. }}$ and $\mathrm{C}_{\text {e.v. }}$ (each district's $2^{\text {nd }}$ position). At the same time, the range of intervals for the first coefficient was 21-28 (difference - 7), the second - 26.3-30.96 (4.66), the third - 1.52.077 (0.577), and the fourth $-0.824-1(0.176)$. 
Table 2. The Clusters' Average Value of Sacral HCM of National Status and UNESCO World Heritage List in the Carpathian region, Ukraine

\begin{tabular}{|c|c|c|c|c|c|}
\hline Clusters & 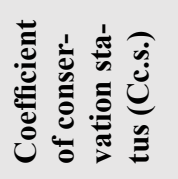 & 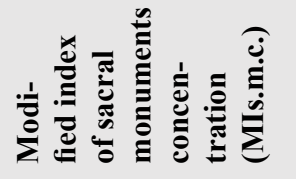 & 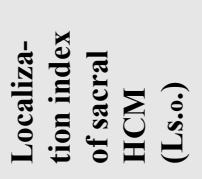 & 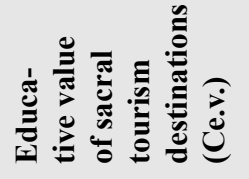 & 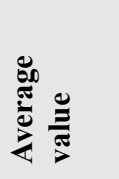 \\
\hline 1 Cluster & 6.96 & 8.75 & 0.768 & 0.800 & 2.47 \\
\hline 2 Cluster & 2.71 & 3.19 & 0.249 & 0.898 & 1.18 \\
\hline 3 Cluster & 18.20 & 19.51 & 0.968 & 0.823 & 4.10 \\
\hline 4 Cluster & 11.08 & 14.56 & 0.941 & 0.962 & 3.48 \\
\hline 5 Cluster & 25.39 & 28.63 & 1.621 & 0.928 & 5.75 \\
\hline 6 Cluster & 41.10 & 41.41 & 2.333 & 0.837 & 7.59 \\
\hline Average value & 12.58 & 14.53 & 0.933 & 0.873 & - \\
\hline
\end{tabular}

Source: authors of paper

And, finally, the sixth district cluster is formed of only 4 administrative districts, namely, Kosiv, Pustomyty, Zhovkva and Skole, all of them manifesting the highest average geometrical values in respect to the first three parameters: $\mathrm{C}_{\text {c.s. }}=41.1 ; \mathrm{MI}_{\text {s.m.c. }}=41.41$, and $\mathrm{L}_{\text {s.o. }}=2.33$. Though highly attractive in this cluster (0.84), $\mathrm{C}_{\text {e.v. }}$ takes a back seat to the fifth, fourth and second clusters. Nonetheless, the aforesaid facts pointedly confirm the formation on the territory of these administrative-territorial units of the best preconditions for the high-performance tourism and excursion activity. We cannot but accentuate that the intervals of the extreme values for $\mathrm{C}_{\text {c.s. }}$ and $\mathrm{MI}_{\text {s.m.c. }}$ are very high and exceed the same for all other clusters. Thus, the $\mathrm{C}_{\text {c.s. }}$ manifests the values of 35-47.4 ( $1^{\text {st }}$ position), $\mathrm{MI}_{\text {s.m.c. }}-38-44.07\left(2^{\text {nd }}\right)$, and it is only the $\mathrm{L}_{\text {s.o. }}$ that shows $1.56-2.96\left(4^{\text {th }}\right)$, and the $\mathrm{C}_{\text {e.v. }}-0.67-1\left(3^{\text {rd }}\right.$ $\left.-4^{\text {th }}\right)-$ see Fig.3.

Following the results of the cluster and pointbased analysis for the purpose of management of sacral HCM resource component, all of the aforesaid preconditions form here an essential potential for the development and efficient management of tourism and excursion activity in Carpathian region, which is annually visited by over 1.5 million tourists. As of this day, foreign and domestic tourists are already served with a number of excursion and pilgrimage tours in Chernivtsi and Ivano-Frankivsk Oblasts, developed and offered by us to the local tourist business. The tours, in the first place, coincide with the territories of the third, fifth and sixth clusters as parts of the Hutsul Meso-District in the southeast and the Bukovynian Ukrainian-speaking and Romanian-speaking microdistricts in the Prypruttia, and in the second, have good perspectives to be incorporated in the religious pilgrimage routes to monasteries and churches under the aegis of the UNESCO ("Sucevița", "Voronets", etc) in the Județul Suceava in Romania.
As follows from this study, intensification of managerial solutions for pilgrimage and excursions in the CRTR's first two clusters is possible through cooperation with staff of respective specialized departments of higher education establishments. To make sacral HCMs more popular it is necessary to develop a transborder strategy of their management in close cooperation with local self-governments, religious communities and their eparchies in border regions of the EU and Ukraine. The bodies and the communities should cooperate to help preserve, protect and restore historic sacral places and objects financed by grants and other funds. The state should develop and realize its program for the development of cultural tourism, and intensely promote the whole Carpathian Region (EU and Ukraine) as a brand and cultural focus within Europe.

Such monuments of folk architecture as wooden sacral structures, the most important of which are included into the UNESCO World Heritage List should become the important objects of unified tourism management in the EU and Ukraine. For example, in addition to the Wooden Architecture Route (Szlak architektury drewnianej), a major tourist route in Poland (507 objects inclusive of those from the UNESCO World Heritage List), and the UNESCO Wooden Churches of the Marmaros in Romania, managers of international tour operators would also have in mind such routes and tours as Sacral Monuments of the Roztochchia, Boykivshchyna and Hutsulshchyna in the Ukrainian Carpathians. All these would increase the competitiveness of the HCMoriented tourism industry, be helpful in ascertainment of specifically attractive territories to be invested into, and help integrate the Carpathian Region of Ukraine into the common cultural and tourism space of the EU countries. 


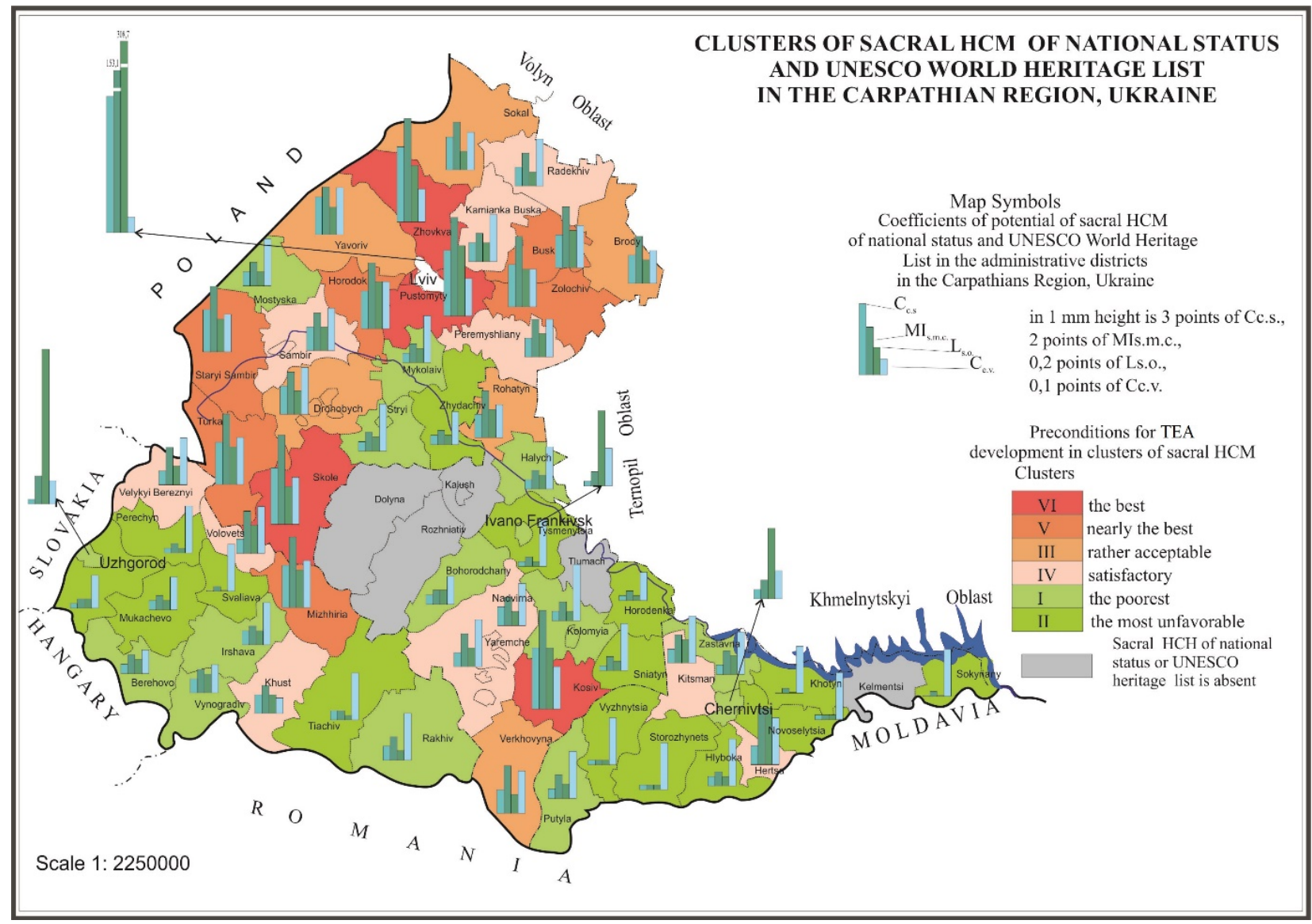

Fig. 3. The Quality of Clusters of Sacral HCM of National Status and UNESCO World Heritage List in the Carpathian Region, Ukraine

\section{Conclusions.}

As follows from the results of point-based assessment of the levels of very good, good, sufficient and average reserves of sacral HCM, the CRTR features districts of different hierarchy. The RoztotskoBoykivskyy Meso-District in the northwest, being the largest and showing sufficient, good and very good sacral HCM reserves (less than 100 points), is represented by 22 administrative districts and the City of Lviv. The Hutsul Meso-District in the southeast (average, good and very good reserves, less than 120 points, with no districts possessing sufficient reserve) covers 6 administrative units, 5 of which are located in the Peredkarpattia. And the last, the Bukovynian Ukrainian-speaking (sufficient reserve, 81-100 points) and the Romanian-speaking (very good reserve, less than 60 points) micro-districts in Prypruttia are quantitatively the smallest formations since they are represented by 1 district each.

Almost the most unfavourable preconditions for sacral HCMs -based and fully linked to Manhattan Matrix (Step 19) TEA have been formed in the first (12 administrative districts and 2 oblast centers), and the most massive (16 administrative units) second district clusters where 4 assessed coefficients $\left(\mathrm{C}_{\text {c.s. }}\right.$, $\mathrm{MI}_{\text {s.m.c. }}, \mathrm{L}_{\text {s.o. }}$ and $\mathrm{C}_{\text {e.v. }}$ ) predominantly showed $5^{\text {th }}$ and the last $6^{\text {th }}$ ranking positions respectively. The fourth cluster with its satisfactory ( predominantly $4^{\text {th }}$ position) reserve for TEA-related development in 10 districts and 1 city of oblast subordination is intermediate between the aforesaid two clusters and those that manifest the very good sacral HCM management figures (third, fifth, sixth clusters). Among all values shown by these three, it is the sixth cluster that takes the lead. Though represented by only 4 administrative districts, it shows the highest average geometrical values for the $\mathrm{C}_{\text {c.s. }}=41.1 ; \mathrm{MI}_{\text {s.m.c. }}=41.41$ and $\mathrm{L}_{\text {s.o. }}=2.33$ $\left(1^{\text {st }}\right.$ position $)$. The third and the fifth clusters, with 6 administrative districts each, predominantly rank $3^{\text {rd }}$ and $2^{\text {nd }}$ respectively which means that the preconditions for the tourism and excursion activity, development of pilgrimage and religious tourism, creation of a competitive tourism product with tour presentation within the CRTR are rather acceptable. The city of Lviv, manifesting absolutely different values and linkage closeness as possessed by all other regional units, requires its own unique strategy of management of sacral HCMs in the quality of the seventh cluster. 


\section{References}

Beidyk, O., 2001. Rekreacijno-turysts'ki resursi Ukrai'ny: metodologija ta metodika analizu, terminologija, rajonuvannja : monografija. [Recreational and tourist resources of Ukraine: methodology and methods of analysis, terminology, zoning: monograph]. Kyiv. Kyiv University. 395. (in Ukrainian).

Blishch, V., 2014. Jetnograficheskij turizm kak faktor povyshenija ustojchivosti turisticheskogo kompleksa respubliki Belarus' [Ethnographic tourism as a factor of raising the sustainability of the tourism complex in the Republic of Belorussia]. Entrepreneurship in Belarus: experience of formation and prospects of development, Minsk, 33-41 (in Russian).

Bozhuk, T., 2008. Ocinka sakral'no-turystychnyh ob'jektiv [Evaluation of sacral tourist sites]. Scientific Bulletin of Chernivtsi University: a collection of scientific papers. Geography Chapter. Chernivtsi, 391. 193-202. (in Ukrainian with English summary)

Chaikina, E., 2017. Kul'tovye obsiekty korennyh narodov Juzhnoj Sibiri: problemy i perspektivy ih ispol'zovanija $\mathrm{v}$ industrii turizma [Religious sites of indigenous peoples of Southern Siberia: problems and prospects of their use in the tourism industry]. Kuzbass geographers, Kemerovo, 107 112. (in Russian) https://doi.org/10.21603/25422448-2017-4-56-59

Danilieva, Yu., 2012. Palomnyc'kyj turyzm v Ukrai'ni: vytoky, riznovydy, perspektyvy [Pilgrimage tourism in Ukraine: origins, varieties, prospects]. Historical notes, Kyiv, 36. 73-80. (in Ukrainian with English summary)

Dobynda, I., 2014. Harakterystyka sakral'nyh pam'jatok Volyns'koi' oblasti ta i'hnje terytorial'ne poshyrennja [Characteristics of sacral monuments of Volyn Oblast (region) and their territorial localization]. Geopolitics and Ecogeodynamics of the Regions. Crimean Federal University named after V. Vernadskyi, Ch. 10, 2, 515-519. (in Ukrainian)

Dobynda, I., 2016. Istoryko-kul'turni rekreacijni resursy poselen' Volyns'koi' oblasti: suspil'nogeografichna ocinka [Historical and cultural recreational resources of settlements of Volyn Oblast (region): social and geographical rating]. Chernivtsi, Chernivtsi National University, 20. (in Ukrainian with English summary)

du Cros, H. \& Johnston, C., 2002. Tourism tracks and sacred places: Pashupatinath and Uluru. Case studies from Nepal and Australia. Historic Environment, 16, 2, 38-42.

Hordyskyi, Y. \& Manko, A., 2012. Problemy i perspektyvy rozvytku turyzmu u Ternopil's'koi' oblasti [Problems and prospects of tourism development in Ternopil Oblast (region)]. Bulletin of the University of Lviv. International Relations Series. 29, 1, 36-47 (in Ukrainian).

Khairetdinova, O., Zaripova, D. \& Khisamutdinova, A., 2016. Perspektivy razvitija sakral'nogo turizma na Juzhnom Urale [Prospects for the development of sacral tourism in the South Urals]. Scientific Almanac, Ufa, 2-4 (16), 121-125. (in Russian)

Kostashchuk, I. \& Hutsuliak, A., 2014. Sakral'noturystychnyj potencial Chernivec'koi' oblasti: osoblyvosti formuvannja ta vykorystannja [Sacral and tourist potential of Chernivtsi Oblast (region): features of formation and use]. Chernivtsi University Scientific Bulletin: Collection of Scientific Papers, 696, 108-110. (in Ukrainian with English summary)

Kostashchuk, I., 2010. Metodyka ocinky sakral'noturystychnyh resursiv regionu (na prykladi Chernivec'koi' oblasti) [Methodology of sacral tourism resources rating (case of Chernivtsi Oblast (region)]. Chernivtsi University Scientific Bulletin: Collection of Scientific Papers, 519-520, 81-86. (in Ukrainian with English summary)

Kostashchuk, I., 2017. Metodyka bal'noi' ocinky religijnoturystychnyh ob'jektiv [Methods of point rating of religious and tourist sites]. Geography and Tourism. 41, 12-21. (in Ukrainian with English summary)

Kostashchuk, I., 2018. Religijnyj prostir Ukrai'ny: suspil'nogeografichne doslidzhennja: monografija [Religious Space of Ukraine: Social and Geographical Research: Monograph], Chernivtsi, 616. (in Ukrainian)

Kostashchuk, I., 2019 a. Formuvannja religijnogo prostoru ta jogo vplyv na suspil'ni procesy [Formation of the religious space and its influence in the social processes] (Unpublished doctoral dissertation), the Institute of Geography of National Academy of Sciences, Kyiv, 692 (in Ukrainian with English summary)

Kostashchuk, I., 2019 b. Formuvannja religijnogo prostoru ta jogo vplyv na suspil'ni procesy [Formation of the religious space and its influence on the social processes] (Abstract), the Institute of Geography of National Academy of Sciences, Kyiv, 40 (in Ukrainian with English summary)

Kravtsiv, B., Hryniv, L., Kopach, M. \& Kuzyk, S., 1999. Naukovo-metodychni zasady reformuvannja rekreacijnoi' sfery [Scientific and methodological foundations of reform of the recreational sphere], Lviv: National Academy of Ukraine, 78 (in Ukrainian).

Krool, V., Vdovichen, A. \& Hyshchuk, R., 2018. Historical and Cultural Heritage of the Region and its Opportunities in Tourism and Excursion Activities (Case of Chernivtsi Region, Ukraine). GeoJournal of Tourism and Geosites, Year XI, 23, 3, 808-823. https://doi.org/10.30892/gtg.23316-330

Levi, D. \& Kocher, S., 2009. Understanding Tourism at Heritage Religious Sites. Focus, 6, 17-21. https:// 
doi.org/10.15368/focus.2009v6n1.2

Liubitseva, O., 2009. Religijna sytuacija v Ukrai'ni ta i'i' regional'ni osoblyvosti. [The religious situation in Ukraine and its regional features]. Ukrainian Geographical Journal. Kyiv. 4. 28-32 (in Ukrainian with English summary)

Lytvyn, I., 2014. Religijnyj turyzm v Ukrai'ni (90-i rr. XX st. - s'ogodennja) [Religious tourism in Ukraine (1990 - today)]. Scientific Journal of National Pedagogical University named after M. Dragomanov, Historical Sciences, Kyiv, 6 (12), 280287. (in Ukrainian with English summary)

Malska, M. \& Antoniuk, N., 2008. Mizhnarodnyj turyzm i sfera poslug [International tourism and services], Kyiv, 661. (in Ukrainian)

Olsen, D. H. \& Timothy, D. J., 2006. Tourism, Religion and Spiritual Journeys. NY-London: Routledge. Published in the Taylor \& Francis e-Library, 304. https://doi.org/10.4324/9780203001073

Panchenko, S., 2019. Upravlinnja sferoju turyzmu na specyfichnomu rynku Ukrai'ny [Management of tourism in the specific market of Ukraine]. Problems of innovation and investment development: Economics and Management, Kyiv, 18, 8592. (in Ukrainian with English summary) https:// doi.org/10.33813/2224-1213.18.2019.9

Polyvach, K., 2007. Kul'turna spadshhyna ta i'i' vplyv na rozvytok regioniv Ukrai'ny (suspil'nogeografichne doslidzhennja) [Cultural heritage and its influence on the development of regions of Ukraine (social and geographical research) (The abstract)], Kyiv, 24 (in Ukrainian with English summary)

Polyvach, K., 2012. Kul'turna spadshhyna ta i'i' vplyv na rozvytok regioniv Ukrai'ny: monografija [Cultural Heritage and its Influence on Development of Regions of Ukraine: monograph], Kyiv, 208 (in Ukrainian).

Pryimak, D., 2015. Religijne palomnyctvo jak faktor rozvytku suchasnogo turyzmu [Religious pilgrimage as a factor of the development in modern tourism]. Hileia: Bulletin Sciences, Kyiv, 100, 149152. (in Ukrainian with English summary)

Rai, R. \& Griffin, K., 2015. Religious Tourism and Pilgrimage Management, UK-USA, 2015, 327.

Shackley, M., 2001. Management challenges for religionbased attractions. Sacred World Heritage Sites: Balancing Meaning with Management Tourism Recreation Research, V 26, Issue 1, 5-10. https:// doi.org/10.1080/02508281.2001.11081171

Shepherd, R. \& Huimin, Gu., 2012. Tourism, heritage, and sacred space. Wutai Shan, China. Journal of Heri- tage Tourism, 7, 145-161. https://doi.org/10.1080 /1743873X.2011.637630

Shykerynets, V., 2012. Religijnyj turyzm jak odyn iz naprjamkiv rozvytku turystychnoi' galuzi IvanoFrankivs'koi' oblasti [Religious tourism as one of directions of development of the tourist branch of Ivano-Frankivsk Oblast (region)]. Collection of the scientific works. The efficiency of public administration, 30, 241-246. (in Ukrainian with English summary)

Smirnov, I., 2015. Logistychna organizacija turystychnogo prostoru (na prykladi sakral'nogo turyzmu) [Logistic organization of tourist space (based on the example of sacral tourism)]. The development of science in the XXI century, Kharkiv, 89-95. (in Ukrainian)

Taylor, K., 2004. Cultural heritage management: a possible role for charters and principles in Asia. International Journal of Heritage Studies, 10, Issue 5, 417-433. https://doi.org/10.1080/135272504200 0299045

Vdovichen, A. \& Hyshchuk, R., 2019. Historical and cultural heritage as a factor of tourism and excursion activities in the euroregion "Upper Prut" of Chernivtsi oblast. Tourism of XXI: Global Challenges and Civilizational Values, Kyiv, 16-18.

The UNESCO World Heritage List of Ukraine, viewed 24 May 2020, Retrieved from: https://whc.unesco. org/en/statesparties/ua

State Register of National Cultural Heritage in Chernivtsi Oblast, viewed 24 May 2020, Retrieved from: https://web.archive.org/web/20081231045810/ http://www.heritage.com.ua/reestry/index. php?id $=75$

State Register of National Cultural Heritage in IvanoFrankivsk Oblast, Retrieved from:https://web. archive.org/web/20070303213722/http://www. heritage.com.ua/reestry/index.php?id $=60$

State Register of National Cultural Heritage in Lviv Oblast, viewed 24 May 2020, Retrieved from: https:// web.archive.org/web/20070304014934/http:// www.heritage.com.ua/reestry/index.php?id=64

State Register of National Cultural Heritage in Zakarpattia Oblast, viewed 24 May 2020, Retrieved from: https://web.archive.org/web/20070304014721/ http://www.heritage.com.ua/reestry/index. php?id $=58$

List of monuments of urban planning and architecture in the Ukrainian SSR of state status protection, viewed 24 May 2020, Retrieved from: https:// zakon.rada.gov.ua/laws/show/442-79-\%D0\%BF/ print1382546247591179 